\title{
Food allergy and asthma
}

\author{
*J Andrew Bird ${ }^{a}$, A Wesley Burks ${ }^{\mathrm{a}}$ \\ a Department of Pediatrics, Duke University Medical Center, North Carolina, USA
}

Received 31st January 2009; revised version received 29th April 2009; accepted 4th May 2009; online 9th July 2009

\begin{abstract}
Food allergy and asthma commonly co-exist in the same patient with approximately one-third of children with food allergy having asthma. When both atopic conditions are present a food allergic patient is placed at greater risk of having a fatal reaction from food allergen exposure. For this reason asthma should be diligently managed in a food allergic patient and these patients should be carefully instructed on allergen avoidance and the proper use of self-injectable epinephrine. This review summarises the available literature regarding patients with both food allergy and asthma specifically looking at disease prevalence, IgE-mediated effects on the lower respiratory tract secondary to foods, the interplay of food additives and asthma, and food allergy as a risk factor for asthma morbidity with practical applications for clinicians.

(C) 2009 General Practice Airways Group. All rights reserved.

JA Bird and AW Burks. Prim Care Resp J 2009; 18(4): 258-265.

doi:10.4104/pcrj.2009.00036
\end{abstract}

Keywords food, allergy, asthma, prevalence, anaphylaxis, management

\section{Contents}

Abstract

Introduction

Prevalence of asthma and food allergy

Food allergy and asthma: public perception

258

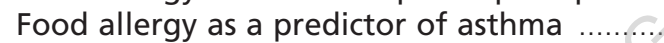

259

Lower respiratory tract reactions to foods

259

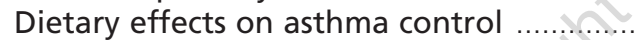

259

Food additives and asthma

260

Occupational asthma

Food-induced anaphylaxis and asthma

\section{Introduction}

Food allergy is defined as an adverse immune response to food proteins. Reactions may be either IgE-mediated or nonIgE-mediated. IgE-mediated reactions typically involve the skin, gastrointestinal and respiratory tracts, and include symptoms such as urticaria, angioedema, vomiting, diarrhoea, asthma or stridor. ' Wheezing is a common manifestation of food allergy in association with other systemic symptoms, but it is seldom the only symptom. While dietary manipulation rarely results in improved asthma control, children with asthma and food allergy are more likely to have fatal allergic reactions to food; ${ }^{2}$ therefore, aggressive asthma control must be achieved in this patient population. This review explores the relationship between food allergy and asthma and gives practical applications for the clinician.

\section{Prevalence of asthma and food allergy}

Western countries have noticed an increase in the prevalence of asthma and allergies since about 1960. Devenny et al. showed an increase in the prevalence of children with asthma - as reported by parental-completed questionnaires - in Aberdeen, UK, from less than $5 \%$ in 1964 to approximately

\footnotetext{
* Corresponding author: Dr J Andrew Bird, Department of Pediatrics, Duke University Medical Center, DUMC, Box 2644, Durham, North Carolina 27710, USA.. Tel: +919-681-2949 Fax: +919-668-3750 E-mail:john.bird@duke.edu
} 
$25 \%$ in $1999 .{ }^{3}$ Between 1980 and 1996 the incidence of selfreported asthma in the United States increased from 2.5 per 1000 to 6.0 per $1000 .{ }^{4}$ However, it is important to note that recent surveys have shown asthma prevalence to be plateauing in developed countries such as Belgium, ${ }^{5}$ Great Britain, ${ }^{6}$ Singapore, ${ }^{7}$ Hong Kong, ${ }^{8}$ and Switzerland. ${ }^{9}$ According to the National Health Interview Survey in the USA it was estimated that an annual average of 20 million people had a diagnosis of asthma between 2001 and 2003. Of these, 6.2 million were children less than 18 years-old. ${ }^{10}$

There is also evidence that the prevalence of food allergy has increased in the past 10 to 15 years. Reports from the USA and the UK have shown approximately a two-fold increase in the number of children with peanut allergy with more than $1 \%$ of children affected. ${ }^{11-13}$ The prevalence of IgE-mediated food allergy in the USA varies between $2-5 \% .{ }^{14}$ It is greater in the pediatric population than in adults, with estimates of $6-8 \%$ in children under 5 years old and $3-4 \%$ in adults. ${ }^{15}$ Reports in Europe suggest the prevalence of food allergy to be between 0.3 and $7.5 \%$ in children and $2-4 \%$ in adults. ${ }^{16,17}$ It is also seen more often in individuals with atopic dermatitis.

Various factors in a Westernised lifestyle have been proposed as possible links to an increase in atopy, though none have been proven. These factors include:

1. Increased exposure to house dust mite due to people spending more time indoors as well as changes in modern housing being more favourable for house dust mite growth..$^{18}$

2. The "hygiene hypothesis" suggests that "declining family size, improved household amenities and higher standards of personal cleanliness have reduced opportunities for cross-infection in young families." 19 In turn, the decreased exposure to microorganisms has been theorised to increase susceptibility to allergic diseases by altering immune system development.

3. Epidemiologic studies have linked obesity with the development and severity of asthma. ${ }^{20}$

4. Decreased antioxidant intake and increased fat consumption in the Western diet have been implicated, though results have been inconclusive in proving the link between allergy, asthma and diet. ${ }^{21}$

5. Children raised on a farm have been shown to have reduced prevalence of allergic disease. One study suggests that consumption of unpasteurised milk by children raised on farms may contribute to decreased allergic sensitisation. ${ }^{22}$

\section{Food allergy and asthma: public perception}

The public perception of the role of food allergy in asthma control is different from what has been proven in medical studies. Dawson et al. reported that $64 \%$ of parents with asthmatic children in New Zealand had made dietary changes believing this would help control their child's asthma. ${ }^{23}$ In another study looking at questionnaires given to asthma clinic patients, $61 \%$ reported that they had made dietary changes to improve their asthma control, and of those patients $79 \%$ believed that it helped. ${ }^{24}$

\section{Food allergy as a predictor of asthma}

Considering both food allergy and asthma together, approximately one third of children with food allergy have asthma and $4-8 \%$ of children with asthma have food allergies. ${ }^{25,26}$ Developing asthma has been linked to certain food sensitivities. Tariq et al. looked at the Isle of Wight cohort and found that children with egg allergy as an infant were more likely to develop asthma or allergic rhinitis with an odds ratio of 5.0. ${ }^{27}$ Similarly, Rhodes et al. ${ }^{28}$ examined a cohort of 100 babies from atopic parents in Poole, England. In this cohort respiratory events were reported annually, skin prick tests were done, and total serum IgE measurements were made during the first five years of life. They found that a positive skin prick test response to hen's egg, cow's milk, or both, in the first year of life was independently predictive of adult asthma with an odds ratio of 10.7. Studies performed by Gustafsson ${ }^{29}$ and Kotaniemi-Syrjanen ${ }^{30}$ found similar results in smaller cohorts followed over shorter periods of time. Kotaniemi-Syrjanen also reported sensitivity to wheat as being predictive of the development of childhood asthma.

\section{Lower respiratory tract reactions to foods}

A few foods cause the majority of reactions. In young children in the USA the most common causal foods are cow's milk (2.5\%), egg $(1.3 \%)$, peanut $(0.8 \%)$, wheat (approximately $0.4 \%)$, soy (approximately $0.4 \%$ ), tree nuts $(0.2 \%)$, fish $(0.1 \%)$ and shellfish $(0.1 \%) .^{1}$ It is believed that allergies to soy and wheat will resolve by school age in the majority of young children, though rigorous studies have not been performed. ${ }^{31}$ Recent studies have shown that cow's milk allergy is resolved in $19 \%$ of children by the age of 4 years, $42 \%$ by age 8 years, $64 \%$ by age 12 years, and $79 \%$ by the age of 16 years. ${ }^{32}$ Egg allergy typically resolves in $4 \%$ of children by the age 4 years, $12 \%$ by 6 years, $37 \%$ by 10 years, and $68 \%$ by 16 years. ${ }^{33}$ Peanut, tree nut, and seafood allergies are more likely to be persistent. In adults in the USA the most common allergens are shellfish $(2 \%)$, peanut $(0.6 \%)$, tree nuts $(0.5 \%)$, and fish $(0.4 \%) .{ }^{1}$ In addition to these foods, the European Union requires sesame, mustard, celery, sulphites, and lupin to be declared on food labels. ${ }^{34}$ Allergic reactions to fruits and vegetables are more often reported in Europe with Rosaceae fruits and vegetables topping the list of reported allergens in France. ${ }^{17}$ 
The most common pulmonary manifestation of IgEmediated food allergy is wheezing. This may occur after ingestion of the food allergen or after exposure to aerosolised particles of the allergen. Wheezing may develop when food such as fish, egg or shellfish is cooked in a confined space..$^{35}$ Fish allergen has even been detected from air samples in a fish market by using a competitive IgE immunoassay. ${ }^{36}$ Peanuts and tree nuts have been implicated as causing allergic reactions when aerosolised in an airplane. ${ }^{37}$ The most widespread epidemic of airborne food-induced asthma has been reported in Barcelona. ${ }^{38}$ Unloading soybean and the resulting soybean dust at a local port was linked to episodic epidemics of sudden, severe and sometimes fatal asthma attacks which decreased after filtering methods were instituted to decrease the amount of aerosolised soybean.

Several studies have looked at reactions to foods after double-blind placebo-controlled food challenges (DBPCFC), the gold standard for diagnosing food allergy. Rarely is wheezing alone described as the presenting symptom. In 1992 Bock published a report of 279 asthmatic children with a history of food-induced wheezing who underwent DBPCFCs. ${ }^{39}$ One hundred and sixty-eight $(60 \%)$ of these children had at least one organ system affected upon challenge with the suspected food. Sixty-seven of the 168 children (40\%) had wheezing. Only five patients had wheezing as the only symptom. The same group reported that out of 188 patients with food allergy but without a history of wheezing after ingestion, only $10(5 \%)$ had wheezing along with reactions in other organ systems and none had wheezing alone.

James et al. reported DBPCFCs in 320 patients (aged 6 months to 30 years) with atopic dermatitis and food hypersensitivity. ${ }^{40}$ More than half of these patients had a prior diagnosis of asthma and all had sensitivities to multiple foods. Blinded challenges confirmed the presence of food allergy in $205(64 \%)$ of these patients with reactions in at least one organ system. Respiratory reactions were experienced in almost two-thirds of the patients (nasal, 70\%; laryngeal, 48\%; pulmonary, 27\%). Overall 17\% (34 patients) developed wheezing as part of their reaction. Spirometry was performed in a subset of patients undergoing challenges. Thirteen of those experienced lower airway symptoms but only six had a decrease of more than $20 \%$ in the first second of exhalation. Wheezing as the sole manifestation was rare.

In another study 300 asthmatic patients (aged 7 months to 80 years) were screened in a respiratory clinic. ${ }^{41}$ DBPCFCs were performed in 25 of these patients suspected of having food-related asthma based on history and/or positive tests of food-specific lgE antibodies. Only six (2\%) of these patients had food-induced wheezing. All six patients were children from 4 to 17 years of age.
In addition to those studies, reports from Novembre, ${ }^{42}$ Oheling, ${ }^{25}$ Businco, ${ }^{43}$ Hill, ${ }^{44}$ Spergel ${ }_{1}^{45}$ and Yazigoclu ${ }^{46}$ support these findings. Blinded challenges have confirmed that respiratory reactions are most often caused by peanut, tree nuts, egg, milk, soy, fish, and shellfish. ${ }^{47-50}$ Peanuts and tree nuts seem to play a very prominent role, with Sampson et al. reporting 25 episodes of wheezing in 101 atopic children with acute reactions to peanut. ${ }^{48}$

\section{Dietary effects on asthma control}

Investigators have looked at the role of diet in the aetiology of asthma. A single-blind prospective study performed by Yusoff et al..$^{51}$ looked at the effect of egg and milk avoidance in 22 asthmatic children between the ages of 3 and 14. Assignment to either the avoidance group or the control group was determined by parental choice. Children in the experimental group that were able to perform peak flow testing had a significant change in peak expiratory flow (PEF) rate as compared to the control group - leading the investigators to conclude that an egg- and milk-free diet can reduce atopic symptoms and improve lung function in asthmatic children.

Similar results have not been replicated in adults. A double-blind, crossover, placebo-controlled trial was conducted looking at 20 adults to see if the consumption of dairy products worsened their asthma control. ${ }^{52}$ Ten of the patients perceived that dairy products worsened their asthma. None of the patients had positive skin prick tests to milk. Subjects complied with a dairy-free diet throughout the study. The active challenge was a single-dose drink equivalent to $300 \mathrm{ml}$ of cow's milk. For both forced expiratory volume in one second $\left(\mathrm{FEV}_{1}\right)$ and PEF there were no statistically significant differences in group means between active challenge and placebo challenge, between sequence of administration, or between perceptions. The authors concluded that it is unlikely that dairy products have a specific bronchoconstrictor effect in most patients with asthma, regardless of their perception. In a similar study conducted by Nguyen, ${ }^{53} 25$ adult asthmatic patients without evidence of cow's milk sensitisation showed no evidence of bronchoconstriction following a 14-day period without cow's milk and then a challenge. A more rigorous scientific approach used in the Woods ${ }^{52}$ and Nguyen ${ }^{53}$ studies may explain differences between their outcomes and those reported by Yusoff. ${ }^{51}$ There are currently no published studies in children apart from the Yusoff report showing a benefit to milk and egg exclusion in asthma control. General food avoidance for the treatment of asthma is not currently recommended. ${ }^{54}$

The effect of sodium, potassium, magnesium, antioxidants (vitamin $C$ and $E$ ), and fatty acids on asthma have all been investigated. ${ }^{55-58}$ Despite various reports of improvement in 
bronchial reactivity there is no conclusive evidence of improvement in asthma with dietary control. ${ }^{26}$ Therefore, apart from allergen avoidance in patients with documented IgE-mediated food allergies currently there are no recommendations to avoid any foods in the treatment of asthma. ${ }^{54}$

\section{Food additives and asthma}

Food additives as a trigger of asthma have been a controversial area with little data to support a cause and effect. Patients may perceive that food additives have a role in worsening their asthma, ${ }^{59}$ but studies have shown the prevalence to be much less than $1 \%$ of the total population. ${ }^{60}$ In fact, one survey in Britain of more than 15,000 patients who self-reported challenges found the prevalence of adverse reactions to additives to be from $0.01 \%-0.23 \%$. $^{61}$ There are more than 2500 food additives with few linked as triggers of asthma. Sulfites and monosodium glutamate (MSG) are the most often implicated and the most studied.

Sulfites are used as a preservative and found in many foods. Foods with the highest sulfite content include dried fruits, wine, molasses, sauerkraut, white grape juice, dried potatoes, gravies, fresh shrimp, pectin, corn syrup, pickles, and relishes. ${ }^{54}$ The largest study performed looking at the role of sulfites in asthmatics showed that out of 203 asthmatics tested, five non-steroid-dependent and 16 steroid-dependent asthmatic patients experienced a $>20 \%$ reduction in their $\mathrm{FEV}_{1}$ within 30 minutes following oral challenge. ${ }^{62}$ Twelve of these sulfite reactors were re-challenged with metabisulfite capsules in a double-blind protocol. Only three of seven steroid-dependent patients had a positive response on rechallenge, and only one of five non-steroid-dependent patients had a response to double-blind challenge. The authors estimated the prevalence of sulfite-induced asthma responses to be less than $3.9 \%$ and more prevalent in those with steroid-dependent asthma.

Monosodium glutamate (MSG) is the flavour enhancer that has been held responsible for the "Chinese restaurant syndrome" - which consists of headache, numbness, chest discomfort, weakness, flushing and abdominal discomfort after eating Chinese food. ${ }^{54} \mathrm{~A}$ large study performed at Scripps Research Institute in La Jolla, California challenged 100 asthmatic subjects with 2.5 grams of MSG, 30 of whom reported a history of asthma attacks after eating Chinese food. ${ }^{63}$ The mean change in $\mathrm{FEV}_{1}$ with MSG challenge was no different from that of placebo challenge for any of the patients tested. A randomised, double-blind placebocontrolled MSG challenge conducted by Woods et al. was unable to demonstrate MSG-induced immediate or late asthmatic reactions in a group of 12 adults who had asthma and believed MSG was detrimental to their asthma control. ${ }^{64}$
Of note, there were also no changes in soluble inflammatory markers such as eosinophil cationic protein or tryptase. Reports of a fall in FEV ${ }_{1}$ six hours after MSG ingestion have been published, though it was concluded that this was not associated with Chinese restaurant syndrome. ${ }^{65,66}$

There are a few case reports but no conclusive evidence that other food additives such as carmine, ${ }^{67}$ sunset yellow (yellow dye number 6), amaranth (red dye number 2), erythrosine (red dye number 3 ), annatto, ponceau, ${ }^{68}$ or tartrazine (yellow dye number 5$)^{69}$ will trigger an asthmatic response.

\section{Occupational asthma}

In adults, it has been shown that aerosolised food particles may lead to the development of asthma. Baker's asthma is an example of exposure to aerosolised cereal grain leading to the development of asthma. ${ }^{70}$ Symptoms include coughing and wheezing after exposure to wheat proteins. Skin prick tests to wheat or serum IgE detection to wheat proteins are positive. The risk to a baker of developing baker's asthma is estimated at $0.3 \%$ per year. ${ }^{71}$ Other implicated foods reported to cause occupational asthma include egg, ${ }^{72}$ enzymes used in the cheese industry, ${ }^{73}$ shellfish, ${ }^{74}$ milk, $^{75}$ and carob bean flour. ${ }^{76}$ Pathologically, occupational asthma looks similar to allergic asthma. Oedema, airway smooth muscle hypertrophy and an eosinophilic infiltrate may be observed in both forms. ${ }^{77}$

\section{Food-induced anaphylaxis and asthma}

Food allergy has been identified as an independent risk factor for asthma morbidity. A higher fatality rate of children with asthma was seen in a peanut allergic cohort over a 2- to 14year follow-up. ${ }^{78}$ Out of the 46 subjects in the cohort, four died of an asthma exacerbation. Similarly a diagnosis of asthma was confirmed in 31 of 32 patients with food-related fatalities in a USA physician reported registry. ${ }^{79}$ Peanuts and tree nuts were the most commonly implicated foods, followed by egg and milk. In the UK, eight from eight patients with fatal food-induced anaphylaxis had asthma. ${ }^{80}$

The relationship between asthma and concomitant food allergy has been examined in both adults and children. Ernst et al. investigated a group of asthmatic adults looking specifically to see if frequent inhaled beta-agonist use was associated with life-threatening asthma. ${ }^{81}$ They found that the second most significant risk factor associated with lifethreatening asthma was a history of an asthma attack being precipitated by food. Berns et al. also found an increase in asthma morbidity in adult patients with concomitant food allergies. ${ }^{82}$ Specifically they found that patients with allergies to more than one food had increased asthma hospitalisations, emergency department visits, and use of oral steroids.

Roberts et al. looked at a group of children in England being ventilated for a life-threatening exacerbation of 
asthma. ${ }^{83}$ Out of 19 cases, half had persisting food allergy compared with only $10 \%$ of the controls. Similarly Vogel et al. found in the USA that children admitted to the intensive care unit for an asthma exacerbation were 3.3 times more likely to report at least one food allergy compared with children admitted to a regular nursing floor and 7.4 times more likely to report at least one food allergy compared with children seen in the ambulatory setting. ${ }^{84}$ Recently it has been reported that elevated food-specific IgE levels and allergies to peanut and milk have been associated with increased rates of hospitalisation for asthma in children. ${ }^{85,86}$

Though a clear link between the pathophysiology of food allergy and asthma has not been established, it is suggested that worsening of asthma in patients with an associated food allergy might occur due to four different factors:

1. Immune cells such as $T$ lymphocytes from the intestinal mucosa are activated in food allergic patients..$^{87-89}$ These lymphocytes then stimulate bronchial mucosa leading to bronchial hyperresponsiveness.

2. Food allergy may only be a presenting sign of a patient whose immune response is skewed towards a proinflammatory allergic reaction. ${ }^{82}$

3. Repeated oral exposure of the food allergen or chronic inhalation of food particles may result in chronic cellular activation with pro-inflammatory cytokines released that worsen asthma. ${ }^{26}$

4. Finally, it is suggested that reactions to food ingestion may have been misdiagnosed as asthma exacerbations since food-induced bronchospasm is often seen in anaphylaxis and there is a delay between allergen exposure and the development of respiratory symptoms. ${ }^{90}$

It should be emphasised that patients with food allergy and asthma are at a greater risk of having a fatal or near-fatal outcome than asthmatics without food allergy. ${ }^{91}$ Aggressive treatment of the patient's asthma and education regarding the use of an injectable epinephrine device should always be performed in this patient group.

\section{Managing food allergy and asthma}

Aggressive management of asthma in a patient with underlying food allergy is of the utmost importance since these patients are at increased risk of having fatal or nearfatal anaphylaxis. ${ }^{90}$ Diagnosing food allergy begins with a careful history, taking particular note of the timing of the onset of symptoms in relation to food ingestion. IgE-mediated reactions occur within seconds to minutes of ingestion and rarely beyond two hours. ${ }^{92}$

Diagnostic testing by skin prick or in vitro testing to measure levels of food-specific lgE should be tailored based on the history. An oral food challenge is performed when history and specific testing do not confirm or refute a food allergy convincingly. Oral food challenges are structured protocols in which the patient ingests a suspect food under clinician supervision ${ }^{93}$ - as mentioned above, double-blind placebo controlled food challenges (DBPCFCs) are the gold standard for diagnosing food allergy. All food challenges should be done in settings equipped with the necessary medications, equipment, and staff to treat anaphylaxis, and should only be performed by allergy specialists familiar with food-allergic reactions.

In the case of unexplained asthma exacerbations a food may be investigated as the underlying trigger with careful detail regarding the patient's diet history in relation to exacerbations. Identification of the allergen and elimination along with the assistance of a dietician is often very helpful in preventing inadvertent allergen exposure. Gastroesophageal reflux, vocal cord dysfunction, and exercise-induced anaphylaxis should be included in the differential diagnosis. ${ }^{26}$ Given the higher likelihood of a fatal or near-fatal incident in patients with asthma and food allergy, many allergists will prescribe a self-injectable epinephrine/adrenaline device (e.g. EpiPen, EpiPen, Jr. TwinJect) to any patient with both asthma and food allergy. ${ }^{91}$

Avoidance of the causal food is the mainstay of food allergy treatment. Those affected should receive dietary education as well as education on the proper treatment of anaphylaxis in case of accidental exposure. Comprehensive educational materials are available through the Food Allergy and Anaphylaxis Network (www.foodallergy.org).

\section{Conclusions}

Food allergy and asthma may often coexist, though the incidence of a food contributing to a person's asthma control is extremely uncommon. Particular attention should be given to patients with both food allergy and asthma as these patients have been found to have a higher incidence of fatal or near-fatal anaphylaxis. Dietary management is important for avoiding the causal allergen as well as insuring adequate nutrition. Practitioners should be comfortable in educating patients on the symptoms associated with an allergic reaction, prescribing self-injectable epinephrine devices, and instructing patients in the proper use of such a device.

\section{Conflict of interest declarations}

JA Bird has no conlicts of interest.

AW Burks has received remuneration from the following companies for consultant and advisory board services: ActoGeniX NV, Dannon Co Probiotics, Intelliject, McNeil Nutritionals, Novartis, and Nutricia. He is a minority stockholder in Allertein and MastCell Inc. Over the last year, he has received funding for research projects for which he has served as an investigator or co-investigator from: the National Institutes of Health; the Food Allergy and Anaphylaxis Network; and the Wallace Research Foundation.

\section{References}

1. Sicherer SH, Sampson HA. Food allergy. J Allergy Clin Immunol 2006;117(2 
Suppl Mini-Primer):S470-5.

2. Pumphrey RS. Lessons for management of anaphylaxis from a study of fatal reactions. Clin Exp Allergy 2000;30(8):1144-50. http://dx.doi.org/10.1046/ j.1365-2222.2000.00864.x

3. Devenny A, FAU - Wassall $H$, Wassall $H$, et al. Respiratory symptoms and atopy in children in Aberdeen: questionnaire studies of a defined school population repeated over 35 years. BMJ 2004;329(7464):489-90. Epub 2004 Jun 24. (1468-5833 (Electronic)).

4. Rudd RA, FAU - Moorman JE, Moorman JE. Asthma incidence: data from the National Health Interview Survey, 1980-1996. J Asthma 2007;44(1):65-70. (0277-0903 (Print)).

5. Vellinga A, Droste JH, Vermeire PA, et al. Changes in respiratory and allergic symptoms in schoolchildren from 1996 to 2002, results from the ISAAC surveys in Antwerp (Belgium). Acta Clin Belg 2005;60(5):219-25.

6. Anderson HR, Ruggles R, Strachan DP, et al. Trends in prevalence of symptoms of asthma, hay fever, and eczema in 12-14 year olds in the British Isles, 19952002: questionnaire survey. BMJ 2004;328(7447):1052-3. http://dx.doi.org/10.1136/bmj.38057.583727.47.

7. Wang XS, Tan TN, Shek LP, et al. The prevalence of asthma and allergies in Singapore; data from two ISAAC surveys seven years apart. Arch Dis Child 2004;89(5):423-6. http://dx.doi.org/10.1136/adc.2003.031112

8. Wong GW, Leung TF, Ko FW, et al. Declining asthma prevalence in Hong Kong Chinese schoolchildren. Clin Exp Allergy 2004;34(10):1550-5. http://dx.doi.org/10.1111/j.1365-2222.2004.02064.x

9. Grize L, Gassner M, Wuthrich B, et al. Trends in prevalence of asthma, allergic rhinitis and atopic dermatitis in 5-7-year old Swiss children from 1992 to 2001. Allergy 2006;61(5):556-62. http://dx.doi.org/10.1111/j.1398-9995.2006. 01030.x.

10. Moorman JE, FAU - Rudd RA, Rudd RA, et al. National surveillance for asthma-United States, 1980-2004. MMWR Surveill Summ 2007;56(8):1-54.PMID17365207 OWN - NLM STAT- MEDLINE. (1545-8636 (Electronic)).

11. Grundy J, Matthews S, Bateman B, Dean T, Arshad SH. Rising prevalence of allergy to peanut in children: Data from 2 sequential cohorts. J Allergy Clin Immunol 2002;110(5):784-9. http://dx.doi.org/10.1067/mai.2002.128802

12. Hourihane JO, Aiken R, Briggs R, et al. The impact of government advice to pregnant mothers regarding peanut avoidance on the prevalence of peanut allergy in United Kingdom children at school entry. J Allergy Clin Immunol 2007;119(5):1197-202. http://dx.doi.org/10.1016/j.jaci.2006.12.670

13. Sicherer SH, Munoz-Furlong A, Sampson HA. Prevalence of peanut and tree nut allergy in the United States determined by means of a random digit dial telephone survey: a 5-year follow-up study. I Allergy Clin Immunol 2003;112(6):1203-07. http://dx.doi.org/10.1016/\$0091-6749(03)02026-8

14. American College of Allergy $A$, Immunology. Food allergy: a practice parameter. Ann Allergy Asthma Immunol 2006;96(3 Suppl 2):S1-68.

15. Sicherer SH, Sampson HA. Food Allergy: Recent Advances in Pathophysiology and Treatment. Annu Rev Med 2008;Aug 19 [Epub ahead of print].

16. Bruijnzeel-Koomen C, Ortolani C FAU - Aas, K, Aas K FAU - Bindslev-Jensen, C, et al. Adverse reactions to food. European Academy of Allergology and Clinical Immunology Subcommittee. Allergy 1995;50(8):623-35. (0105-4538).

17. Kanny G, Moneret-Vautrin DA, Flabbee J, Beaudouin E, Morisset M, Thevenin FT. Population study of food allergy in France. J Allergy Clin Immunol 2001; 108(1):133-40. (0091-6749).

18. Custovic A, Simpson A, Woodcock A. Importance of indoor allergens in the induction of allergy and elicitation of allergic disease. Allergy 1998;53(48 Suppl):115-20. http://dx.doi.org/10.1111/j.1398-9995.1998.tb05011.x

19. Strachan DP. Hay fever, hygiene, and household size. BMJ 1989;299(6710):1259-60. http://dx.doi.org/10.1136/bmj.299.6710.1259

20. Sin DD, Sutherland ER. Obesity and the lung: 4. Obesity and asthma. Thorax 2008;63(11):1018-23. http://dx.doi.org/10.1136/thx.2007.086819.

21. Wood LG, Gibson PG. Dietary factors lead to innate immune activation in asthma. Pharmacol Ther 2009 Jul;123(1):37-53. Epub 2009 Apr 15. http://dx.doi.org/10.1016/ j.pharmthera.2009.03.015.

22. Perkin MR, Strachan DP. Which aspects of the farming lifestyle explain the inverse association with childhood allergy? I Allergy Clin Immunol 2006;117(6):1374-81. http://dx.doi.org/10.1016/j.jaci.2006.03.008.

23. Dawson KP, Ford RP, Mogridge N. Childhood asthma: what do parents add or avoid in their children's diets? N Z Med J 1990;103(890):239-40.

24. Woods RK, Weiner J, Abramson M, Thien F, Walters EH. Patients' perceptions of food-induced asthma. Aust N Z J Med 1996;26(4):504-12.

25. Oehling A, Baena Cagnani CE. Food allergy and child asthma. Allergol Immunopathol (Madr) 1980;8(1):7-14.

26. Roberts G, Lack G. Food allergy and asthma--what is the link? Paediatr Respir Rev 2003;4(3):205-12. http://dx.doi.org/10.1016/S1526-0542(03)00058-7

27. Tariq SM, Matthews SM, Hakim EA, Arshad SH. Egg allergy in infancy predicts respiratory allergic disease by 4 years of age. Pediatr Allergy Immunol 2000;11(3):162-7. http://dx.doi.org/10.1034/j.1399-3038.2000.00077.x

28. Rhodes HL, Sporik R, Thomas P, Holgate ST, Cogswell JJ. Early life risk factors for adult asthma: a birth cohort study of subjects at risk. J Allergy Clin Immunol 2001;108(5):720-5. http://dx.doi.org/10.1067/mai.2001.119151

29. Gustafsson D, Sjoberg O, Foucard T. Sensitization to food and airborne allergens in children with atopic dermatitis followed up to 7 years of age. Pediatr Allergy Immunol 2003;14(6):448-52. http://dx.doi.org/10.1046/j.09056157.2003.00093.x

30. Kotaniemi-Syrjanen A, Reijonen TM, Romppanen J, Korhonen K, Savolainen K, Korppi M. Allergen-specific immunoglobulin E antibodies in wheezing infants: the risk for asthma in later childhood. Pediatrics 2003;111(3):e255-61. http://dx, doi.org/10.1542/peds.111.3.e255

31. Wood RA. The natural history of food allergy. Pediatrics 2003;111(6 Pt 3):16317.

32. Skripak JM, Matsui EC, Mudd K, Wood RA. The natural history of IgE-mediated cow's milk allergy. J Allergy Clin Immunol 2007;120(5):1172-7. http://dx.doi.org/10.1016/j.jaci.2007.08.023

33. Savage JH, Matsui EC, Skripak JM, Wood RA. The natural history of egg allergy. J Allergy Clin Immunol 2007;120(6):1413-17. http://dx.doi.org/ 10.1016/j.jaci.2007.09.040.

34. Sporik R, Henderson J, Hourihane JO. Clinical Immunology Review Series: An approach to a child with allergic disease. Clin Exp Immunol 2009;155(3):37886. (1365-2249).

35. Sicherer SH, Sampson HA. The role of food allergy in childhood asthma. Immunology and Allergy Clinics of North America 1998;18(1):49-60. http://dx.doi.org/10.1016/S0889-8561(05)70346-5.

36. Taylor AV, Swanson MC, Jones RT, et al. Detection and quantitation of raw fish aeroallergens from an open-air fish market. J Allergy Clin Immunol 2000;105(1 Pt 1):166-69. http://dx.doi.org/10.1016/S0091-6749(00)90192-1

37. Sicherer SH, Furlong TJ, DeSimone J, Sampson HA. Self-reported allergic reactions to peanut on commercial airliners. J Allergy Clin Immunol 1999;104(1):186-9. http://dx.doi.org/10.1016/S0091-6749(99)70133-8

38. Anto JM, Sunyer J, Rodriguez-Roisin R, Suarez-Cervera M, Vazquez L. Community outbreaks of asthma associated with inhalation of soybean dust. Toxicoepidemiological Committee. N Engl J Med 1989;320(17):1097-102.

39. Bock SA. Respiratory reactions induced by food challenges in children with pulmonary disease. Pediatr Allergy Immunol 1992;3:188-94. http://dx.doi.org/10.1111/j.1399-3038.1992.tb00048.x

40. James JM, Bernhisel-Broadbent J, Sampson HA. Respiratory reactions provoked by double-blind food challenges in children. Am J Respir Crit Care Med 1994; 149(1):59-64.

41. Onorato J, Merland N, Terral C, Michel FB, Bousquet J. Placebo-controlled double-blind food challenge in asthma. I Allergy Clin Immunol 1986;78(6):1139-46. http://dx.doi.org/10.1016/0091-6749(86)90263-0

42. Novembre E, de Martino M, Vierucci A. Foods and respiratory allergy. J Allergy 
Clin Immunol 1988;81(5 Pt 2):1059-65. http://dx.doi.org/10.1016/00916749(88)90181-9

43. Businco L, Falconieri P, Giampietro P, Bellioni B. Food allergy and asthma. Pediatr Pulmonol Suppl 1995;11:59-60. http://dx.doi.org/ 10.1002/ppul.1950191131

44. Hill DJ, Firer MA, Shelton MJ, Hosking CS. Manifestations of milk allergy in infancy: clinical and immunologic findings. J Pediatr 1986;109(2):270-6. http://dx.doi.org/10.1016/S0022-3476(86)80384-5

45. Spergel JM, Beausoleil JL, Fiedler JM, Ginsberg J, Wagner K, Pawlowski NA. Correlation of initial food reactions to observed reactions on challenges. Ann Allergy Asthma Immunol 2004;92(2):217-24.

46. Yazicioglu M, Baspinar I, Ones U, Pala O, Kiziler U. Egg and milk allergy in asthmatic children: assessment by immulite allergy food panel, skin prick tests and double-blind placebo-controlled food challenges. Allergol Immunopathol (Madr 1999;27(6):287-93.

47. Bock SA, Atkins FM. Patterns of food hypersensitivity during sixteen years of double-blind, placebo-controlled food challenges. J Pediatr 1990;117(4):561-7. http://dx.doi.org/10.1016/S0022-3476(05)80689-4

48. Sampson HA, Mendelson L, Rosen JP. Fatal and near-fatal anaphylactic reactions to food in children and adolescents. N Eng/ J Med 1992;327(6):3804.

49. Burks AW, Mallory SB, Williams LW, Shirrell MA. Atopic dermatitis: clinical relevance of food hypersensitivity reactions. J Pediatr 1988;113(3):447-51. http://dx.doi.org/10.1016/50022-3476(88)80626-7

50. Bock SA. Prospective appraisal of complaints of adverse reactions to foods in children during the first 3 years of life. Pediatrics 1987;79(5):683-8.

51. Yusoff NA, Hampton SM, Dickerson JW, Morgan JB. The effects of exclusion of dietary egg and milk in the management of asthmatic children: a pilot study. $J R$ Soc Health 2004;124(2):74-80. http://dx.doi.org/10.1177/ 146642400412400211

52. Woods RK, Weiner JM, Abramson M, Thien F, Walters EH. Do dairy products induce bronchoconstriction in adults with asthma? I Allergy Clin Immunol 1998;101(1 Pt 1):45-50. http://dx.doi.org/10.1016/S0091-6749(98)70192-7

53. Nguyen MT. Effect of cow milk on pulmonary function in atopic asthmatic patients. Ann Allergy Asthma Immunol 1997;79(1):62-4.

54. Beausoleil JL, Fiedler J, Spergel JM. Food Intolerance and childhood asthma: what is the link? Paediatr Drugs 2007;9(3):157-63. http://dx.doi.org/10.2165/00148581-200709030-00004

55. Pogson ZE, Antoniak MD, Pacey SJ, Lewis SA, Britton JR, Fogarty AW. Does a low sodium diet improve asthma control? A randomized controlled trial. Am J Respir Crit Care Med 2008;178(2):132-8. http://dx.doi.org/ 10.1164/rccm.200802-2870C.

56. Mickleborough TD, Fogarty A. Dietary sodium intake and asthma: an epidemiological and clinical review. Int J Clin Pract 2006;60(12):1616-24. http://dx.doi.org/10.1111/j.1742-1241.2006.01103.x.

57. Fogarty A, Britton J. The role of diet in the aetiology of asthma. Clin Exp Allergy 2000;30(5):615-27. http://dx.doi.org/10.1046/j.1365-2222.2000.00766.x

58. Baker JC, Ayres JG. Diet and asthma. Respir Med 2000;94(10):925-34. http://dx.doi.org/10.1053/rmed.2000.0873.

59. Abramson MJ, Kutin JJ, Rosier MJ, Bowes G. Morbidity, medication and trigger factors in a community sample of adults with asthma. Med J Aust 1995;162(2):78-81.

60. Spergel JM, Fiedler J. Food allergy and additives: triggers in asthma. Immunol Allergy Clin North Am 2005;25(1):149-67. http://dx.doi.org/10.1016/ j.iac.2004.09.012.

61. Young E, Patel $S$, Stoneham M, Rona R, Wilkinson JD. The prevalence of reaction to food additives in a survey population. I $R$ Coll Physicians Lond 1987;21(4):241-7.

62. Bush RK, Taylor SL, Holden K, Nordlee JA, Busse WW. Prevalence of sensitivity to sulfiting agents in asthmatic patients. Am J Med 1986;81(5):816-20. http://dx.doi.org/10.1016/0002-9343(86)90351-7

63. Woessner KM, Simon RA, Stevenson DD. Monosodium glutamate sensitivity in asthma. J Allergy Clin Immunol 1999;104(2 Pt 1):305-10. http://dx.doi.org/ 10.1016/50091-6749(99)70371-4

64. Woods RK, Weiner JM, Thien F, Abramson M, Walters EH. The effects of monosodium glutamate in adults with asthma who perceive themselves to be monosodium glutamate-intolerant. I Allergy Clin Immunol 1998;101(6 Pt 1):762-71. http://dx.doi.org/10.1016/S0091-6749(98)70305-7

65. Moneret-Vautrin DA. Monosodium glutamate-induced asthma: study of the potential risk of 30 asthmatics and review of the literature. Allerg Immunol (Paris) 1987; 19(1):29-35.

66. Allen DH, Delohery J, Baker G. Monosodium L-glutamate-induced asthma. J Allergy Clin Immunol 1987;80(4):530-7. http://dx.doi.org/10.1016/00916749(87)90003-0

67. Burge PS, O'Brien IM, Harries MG, Pepys J. Occupational asthma due to inhaled carmine. Clin Allergy 1979;9(2):185-9. http://dx.doi.org/10.1111/j.13652222.1979.tb01540.x

68. Weber RW, Hoffman M, Raine DA, Jr, Nelson HS. Incidence of bronchoconstriction due to aspirin, azo dyes, non-azo dyes, and preservatives in a population of perennial asthmatics. J Allergy Clin Immunol 1979;64(1):327. http://dx.doi.org/10.1016/0091-6749(79)90080-0

69. Stevenson DD, Simon RA, Lumry WR, Mathison DA. Adverse reactions to tartrazine. J Allergy Clin Immunol 1986;78(1 Pt 2):182-91. http://dx.doi.org/ 10.1016/0091-6749(86)90011-4

70. Hendrick DJ, Davies RJ, Pepys J. Bakers' asthma. Clin Allergy 1976;6(3):241-50. http://dx.doi.org/10.1111/j.1365-2222.1976.tb01903.x

71. Meredith S. Reported incidence of occupational asthma in the United Kingdom, 1989-90. J Epidemiol Community Health 1993;47(6):459-63. http://dx.doi.org/ 10.1136/jech.47.6.459

72. Blanco Carmona JG, Juste Picon S, Garces Sotillos M, Rodriguez Gaston P. Occupational asthma in the confectionary industry caused by sensitivity to egg. Allergy 1992;47(2 Pt 2):190-1. http://dx.doi.org/10.1111/j.13989995.1992.tb00964.x

73. Casper R, Zacharisen MC, Fink JN. Occupational asthma secondary to enzymes used in cheese production. Allergy Asthma Proc 2008;29(4):376-79. http://dx.doi.org/10.2500/aap.2008.29.3134

74. James JM, Crespo JF. Allergic reactions to foods by inhalation. Curr Allergy Asthma Rep 2007;7(3):167-74. http://dx.doi.org/10.1007/s11882-007-0017-z

75. Rossi GL, Corsico A, Moscato G. Occupational asthma caused by milk proteins: report on a case. J Allergy Clin Immunol 1994;93(4):799-801. http://dx.doi.org/ 10.1016/0091-6749(94)90261-5

76. van der Brempt $X$, Ledent $C$, Mairesse M. Rhinitis and asthma caused by occupational exposure to carob bean flour. J Allergy Clin Immunol 1992;90(6 Pt 1):1008-10. http://dx.doi.org/10.1016/0091-6749(92)90480-P

77. Maestrelli P, Saetta M, Mapp C, Fabbri LM. Mechanisms of occupational asthma. Clin Exp Allergy 1997;27 Suppl 1:47-54. http://dx.doi.org/ 10.1111/j.1365-2222.1997.tb01826.x

78. Bock SA, Atkins FM. The natural history of peanut allergy. J Allergy Clin Immunol 1989;83(5):900-04. http://dx.doi.org/10.1016/0091-6749(89)90103-6

79. Bock SA, Munoz-Furlong A, Sampson HA. Fatalities due to anaphylactic reactions to foods. J Allergy Clin Immunol 2001;107(1):191-3. http://dx.doi.org/10.1067/mai.2001.112031

80. Macdougall CF, Cant AJ, Colver AF. How dangerous is food allergy in childhood? The incidence of severe and fatal allergic reactions across the UK and Ireland. Arch Dis Child 2002;86(4):236-9. http://dx.doi.org/10.1136/ adc.86.4.236

81. Ernst $P$, Habbick $B$, Suissa $S$, et al. Is the association between inhaled betaagonist use and life-threatening asthma because of confounding by severity? Am Rev Respir Dis 1993;148(1):75-9.

82. Berns SH, Halm EA, Sampson HA, Sicherer SH, Busse PJ, Wisnivesky JP. Food 
allergy as a risk factor for asthma morbidity in adults. J Asthma 2007;44(5):37781. (0277-0903 (Print)).

83. Roberts G, Patel N, Levi-Schaffer F, Habibi P, Lack G. Food allergy as a risk factor for life-threatening asthma in childhood: a case-controlled study. J Allergy Clin Immunol 2003;112(1):168-74. http://dx.doi.org/10.1067/mai.2003.1569

84. Vogel NM, Katz HT, Lopez R, Lang DM. Food allergy is associated with potentially fatal childhood asthma. J Asthma 2008;45(10):862-6. http://dx.doi.org/10.1080/02770900802444195

85. Simpson AB, Glutting J, Yousef E. Food allergy and asthma morbidity in children. Pediatr Pulmonol 2007;42(6):489-95. http://dx.doi.org/ 10.1002/ppul.20605.

86. Wang J, Visness CM, Sampson HA. Food allergen sensitization in inner-city children with asthma. J Allergy Clin Immunol 2005;115(5):1076-80. http://dx.doi.org/10.1016/j.jaci.2005.02.014

87. Forbes E, Smart VE, D'Aprile A, et al. T helper-2 immunity regulates bronchial hyperresponsiveness in eosinophil-associated gastrointestinal disease in mice. Gastroenterology 2004;127(1):105-18. http://dx.doi.org/10.1053/j.gastro.
2004.03.057

88. Thaminy A, Lamblin C, Perez T, Bergoin C, Tonnel AB, Wallaert B. Increased frequency of asymptomatic bronchial hyperresponsiveness in nonasthmatic patients with food allergy. Eur Respir J 2000;16(6):1091-4. http://dx.doi.org/10.1034/j.1399-3003.2000.16f12.x

89. James JM, Eigenmann PA, Eggleston PA, Sampson HA. Airway reactivity changes in asthmatic patients undergoing blinded food challenges. Am J Respir Crit Care Med 1996;153(2):597-603.

90. Pumphrey RS. Lessons for management of anaphylaxis from a study of fatal reactions. Clin Exp Allergy 2000;30(8):1144-50. http://dx.doi.org/10.1046/ j.1365-2222.2000.00864.x

91. Sicherer SH. Food allergy. Lancet 2002;360(9334):701-10. http://dx.doi.org/10.1016/S0140-6736(02)09831-8

92. Burks AW. History and physical examination in the patient with possible food allergy. UpToDate, version 16.2. 2008:1-13.

93. Burks AW. Diagnostic tools for food allergy. UpToDate, version 16.2. 2008:1-13.

\section{Available online at http://www.thepcrj.org}

